\title{
Beliefs, superstitions and taboos associated with bamboos in Nepal and its implications
}

\begin{abstract}
A.N. Das ${ }^{1}$ and C.P. Mitchell ${ }^{2}$
Bamboos are one of the important natural resources of Nepal. Bamboos have multiple uses and are increasingly used as a replacement of timber for construction purposes. Besides that, its use for craftmaking (woven and unwoven) and furniture has also significantly increased in recent years. For many rural households, which includes socially and economically disadvantaged groups; sale of bamboo and its products is an important source of income and sustaining livelihoods. The promotion of bamboo growing in Nepal can help generate income and can be one of the means for reducing poverty in Nepal. However, there are considerable beliefs, superstition, and taboos associated with bamboos in Nepal, many of which have influenced decision making of households towards bamboo growing in Nepal. The findings of the detailed study on taboos, beliefs and superstitions conducted in the Terai and Midhills and its implications on bamboo growing are discussed in this paper.
\end{abstract}

$\mathbf{T}$ he Tenth Five Year Plan (2002-2007) of Nepal is focused on poverty reduction. Bamboos are increasingly identified as one of the important renewable natural products that can help reduce poverty if grown and managed on sustainable basis (Das, 2002; Poudyal and Das, 2002). Bamboo has intimately been associated with human being since ancient time in Nepal. Very few species can match bamboo in terms of uses as virtually anything can be made of bamboos. Bamboos are an important component of rural farming system, as they play critical role in rural economy and help sustain livelihoods of many rural households (Das, 1992, $1999 \mathrm{a}$ and b). Bamboo handicrafts, furniture, woven products and shoots as vegetables are readily bought and sold and is a source of income for many rural households, that includes socially and economically disadvantaged groups (Das, 1999a and 2002). Bamboos are mostly grown on private farmlands and also occur in natural forests (Das, 2002). They are also now increasingly introduced in community forests. Fifty species of bamboos are already recorded in Nepal (Das, 2004).

Several studies have been conducted on the effect of taboos, beliefs and superstitions on tree planting and their positive and negative impacts on the conservation of forests both in Asia and Africa (Wood, 1966; Wilson, 1989; Kwesiga and Chisumpa, 1990; Raintree, 1991; Shepherd, 1992; Ratikette et al., 1992). In many countries, certain species of tree or simply certain individuals with a special shape have distinctive religious or spiritual connotations. This can often influence people's tree cultivation activities (Foley and Bernard, 1984; FAO, 1985; Chambers et al., 1989). The literature review suggests that there are many taboos, superstitions and beliefs associated with woody perennials in many parts of the world, including Nepal. Such taboos, beliefs and superstitions have both positive and negative impacts on the conservation of natural resources.

Bamboos are associated with ancient civilisation in South and South-East Asia and are not so frequently associated with evil (superstitions, magic) and sadness as it is with youth, flexibility and love (Piper, 1992). In Bangladesh, when a villager is buried a small piece of bamboo is hung above the grave in order to scare away evil spirits (Arens and Beurden, 1978).

Gurung (1989) reported an unwillingness to plant bamboo amongst some villagers in the KakaniKathmandu area, where it was associated with childlessness. According to Carter (1991) the cultivation of bans was surrounded with considerable superstition in the Midhills of Central Nepal. She was told that when planting bans it was essential to avoid its shadow falling on your body. If this happened, it was effectively an invitation to the god of death (Yamraj). Harvesting of bamboo was also restricted to certain days of the week (not Tuesdays or Thursdays) and times of the lunar month. According to her, this may be the main factor, which limited the amount of bamboo grown even though 
it seems so important to the rural people. The other major charges against bamboo are: it impoverishes the soil in which it grows and nothing grows under bamboos (Carter, 1991), a similar finding like in Kerala, India (Boa, 1995; Blowfield, 1995).

This paper analyses the result of the detailed study conducted in eastern Nepal on existing taboos, beliefs and superstitions associated with bamboos. This study is the first comprehensive attempt to investigate the taboos, superstitions and beliefs associated with bamboos, its extent (level of belief) and their possible effect on development of bamboo resources in Nepal.

\section{Research methods}

A multi-faceted research approach was adopted, combining techniques used in the social sciences such as RRA/PRA and those more familiar to biological scientists such as ranking, diagramming, and formal surveys. The use of different methods such as surveys with semi-structured interview, focus group meetings, key informant interviews and personal diaries of some served as a crosscheck (triangulation) on the reliability of information obtained from one method against another to collect the qualitative and quantitative information.

The study was conducted in 13 village development committees (VDCs) of the Terai and Midhills (6 Tharu villages (Morang district) in the Terai, 6 Midhills villages (Dhankuta district) and Kerabari, a village near forests mostly settled by hill migrants(Morang District)). A complete census was carried out in one ward randomly selected out of 9 wards in each of VDCs selected. Households were categorised into growers and nongrowers, and wealth ranking was carried out on the basis of key informant interview with selected male and female residents. Households were randomly selected on proportional basis from each category. Altogether, 199 households in the Terai, 208 in the Midhills and 41 in Kerabari were interviewed with semi-structured and open-ended questions. This information was crosschecked through 58 male and 61 female focus group meetings, and key informant interviews with local political leaders, social workers and teachers.

\section{Results and discussions}

It was found in the present study that there are a considerable number of taboos, superstitions and beliefs regarding bamboo planting and harvesting in Nepal. No other tree species has such a high level of beliefs as those associated with bamboos. The belief in superstitions and taboos associated with bamboos is higher among the households in the Terai than in the Midhills and Kerabari. Most of these taboos and superstitions do not have any rational explanation and only a few are positive toward the conservation of bamboos. The findings of the study are presented in Table 1 and the issues are discussed below.

Table 1 Beliefs, Superstitions and Taboos associated with Bamboos in the Terai, the Midhills and Kerabari

\begin{tabular}{|c|c|c|c|c|c|c|}
\hline \multirow[b]{2}{*}{ Item } & \multicolumn{2}{|c|}{ Terai } & \multicolumn{2}{|c|}{ Midhills } & \multicolumn{2}{|c|}{ Kerabari } \\
\hline & HH. No. & $\% \mathrm{HH}$. & $\begin{array}{l}\text { HH. } \\
\text { No. }\end{array}$ & $\% \mathrm{HH}$. & HH. No. & $\% \mathrm{HH}$ \\
\hline - $\quad$ Believe in taboos and superstitions & 139 & 69.85 & 79 & 37.96 & 16 & 39.02 \\
\hline \multicolumn{7}{|l|}{ - Types of beliefs, taboos and superstitions } \\
\hline 1. Reduces the productivity of the land & 182 & 91.46 & 172 & 82.69 & 39 & 95.12 \\
\hline 2. Women must not plant. & 171 & 85.93 & 138 & 66.35 & 17 & 41.46 \\
\hline $\begin{array}{l}\text { 3. Only to be planted by the oldest male member of the } \\
\text { households }\end{array}$ & 108 & 54.27 & 104 & 50.00 & 12 & 29.27 \\
\hline 4. Make infertile, adult male must not plant. & 106 & 53.27 & 106 & 50.96 & 13 & 31.71 \\
\hline 5. Invites snakes, and wild elephants (Kerabari only). & 116 & 58.29 & 0 & 0 & 19 & 46.34 \\
\hline 6. Cause of quarrel with neighbours. & 66 & 33.17 & 7 & 3.37 & 23 & 56.10 \\
\hline 7. Ghosts and spirits live in clumps. & 65 & 32.66 & 3 & 1.44 & 3 & 7.32 \\
\hline 8. Makes place dirty (Litter). & 38 & 19.10 & 0 & 0 & 6 & 14.63 \\
\hline 9. Thieves and robbers hide in clumps. & 29 & 14.57 & 2 & 0.96 & 0 & 0.00 \\
\hline 10. Should not be planted in front of house. & 23 & 11.56 & 10 & 4.81 & 1 & 2.44 \\
\hline 11. Those who plant will die early. & 10 & 5.03 & 5 & 2.40 & 6 & 14.63 \\
\hline 12. Bamboo dies if planter's shadow falls on bamboos. & 2 & 1.01 & 64 & 30.77 & 9 & 21.95 \\
\hline 13. Planter will die if its shadow will fall on him. & 2 & 1.01 & 79 & 37.98 & 13 & 31.71 \\
\hline 14. Not to be successfully propagated by Women. & 8 & 4.02 & 0 & 0.00 & 1 & 2.44 \\
\hline 15. Not to be planted in the broad daylight. & 0 & 0.00 & 22 & 10.58 & 1 & 2.44 \\
\hline
\end{tabular}


16. People steal bamboos have no future generation.

17. Bamboo will not propagate if woman plants.

18. If bamboo does not grow well that means future generation will also have bleak future.

19. Plants die after flowering and are inauspicious.

20. To be planted using male labourers only.

21. New bamboo shoots (esp. Mal bans) must not to be broken by women and mature men.

22. Not good if new shoot is produced in planting year.

23. Ainjeru in bamboo indicates to be in loan.

24. One should not climb on roof carrying bamboos.

25. Only good (pious) people are able to plant.

26. Will not grow if young / kids plant it.

27. To be planted in March/April only.

28. If planted bamboos expands well then future generation of planter dies and vice versa.

$\begin{array}{cccccc}5 & 2.51 & 0 & 0 & 0 & 0.00 \\ 0 & 0 & 4 & 1.92 & 0 & 0 \\ 0 & 0 & 3 & 1.44 & 0 & 0 \\ 0 & 0 & 2 & 0.96 & 0 & 0 \\ 0 & 0 & 2 & 0.96 & 0 & 0 \\ 0 & 0.00 & 1 & 0.48 & 2 & 4.88 \\ 0 & 0 & 1 & 0.48 & 0 & 0 \\ 0 & 0 & 1 & 0.48 & 0 & 0 \\ 0 & 0 & 1 & 0.48 & 0 & 0 \\ 0 & 0 & 1 & 0.48 & 0 & 0 \\ 1 & 0.50 & 0 & 0 & 0 & 0.00 \\ 0 & 0 & 1 & 0.48 & 0 & 0 \\ 0 & 0 & 1 & 0.48 & 0 & 0\end{array}$

Key: $\mathrm{HH}=$ household

\section{The Terai}

Overwhelming majority of households (61.9\%) in the Terai believes in tabors and superstitions associated with bamboos. The most common belief associated with bamboos was that it reduces the productivity of the land where it grows. The households further elaborated that nothing grows under bamboos, an indication of reduced productivity of the land. They also mentioned that crop productivity declines considerably in the land adjoining bamboo clumps where its shade reaches. There is some rationality behind such beliefs but as the literature review suggests it is not totally true. Singh et al. (1992) studied the effect of bamboo shade on the yield of some agricultural crops in the Midhills of Sikkim, India. The agricultural crops were grown on the terraces in the eastern side of the bamboo grove. The terrace was $2.5-3.0 \mathrm{~m}$ wide and $18-20 \mathrm{~m}$ long. Details were given of light intensity and soil properties and yields of 10 crops at distances from 1 to $17 \mathrm{~m}$ from the bamboos. The results indicate that agricultural land near bamboos can be effectively utilised for growing ginger, turmeric, large cardamom, orchard grass and dinanath grass up to a distance of 11-15 m from the bamboo row. Rice, fingermillet, soybeans, nandi setaria and fine stylo were suitable crops beyond this distance. Available P increased whereas exchangeable $\mathrm{K}, \mathrm{Ca}$ and $\mathrm{Mg}$ decreased with increasing distance from the bamboos, soil $\mathrm{pH}$ and soil organic matter did not vary with distance. Bamboos are still planted but it is likely that they would be planted on a much larger scale if such beliefs were as not as strong. As there is some rationality behind this belief, this is not considered further.
The most commonly held belief in the Terai was that women must not carry out bamboo planting. Bamboo and banana are ekpurukhiya, which means in Maithili or local Tharu dialect "men without future generation". Both banana and bamboo grows from the dormant buds at the root or rhizome, i.e. no seed sown and therefore should not be planted by women. If women plant them, they will become infertile and the bamboo will not grow. Some households mentioned that women must not plant bamboos because it is a customary practice that bamboo planting should not be done by women. During the study, through female focus group meetings, it was found that belief in this is very high among the women. Women also mentioned that, in general, tree planting is the job of men however they can plant other trees (mostly fruit trees) if they wish to but they will not carry out bamboo planting. Some of the households mentioned that women can carry out bamboo planting if they already have children, were old or have no middle aged or old males in the house.

The other most commonly heard and held belief was that bamboo clumps invite vermin like poisonous and dangerous snakes, rodents and unwanted insects and therefore should not be planted very close to the home. Households that believe this will not plant bamboos next to the home because of such a fear.

Over half the households mentioned that they have heard from their parents and forefathers that bamboo planting must be carried out only by the oldest male members, usually the household heads. Many households mentioned that bamboo planting is inauspicious and those who plant may suddenly die of unknown reasons and therefore should be carried 
out strictly by the oldest member of the household. If there are no old males (over 60 years) in the house then it can be carried out by a middle-aged man. The belief in this superstition was deep-rooted among the older households and women than the young families who were generally better educated. Some of the households mentioned that they do not believe in this superstition but when they asked if they would carry out bamboo planting themselves, they pointed out, with hesitation, that they would prefer not to.

One of the other most commonly heard or held belief was that bamboos should not be planted by young male adults, childless married couples and children. If such people plant bamboos then they will be infertile. It was found during the study that most of the bamboo planting was carried out only by the oldest members of the house and not by any young adult male members of the family who, however, can plant other tree species. This has an important implication as bamboo planting is considered a difficult job because the culm offsets of a 2 year old with rhizomes should be dug out from the ground without damaging buds and the planting pits used for such bamboo planting are usually bigger than for tree species.

Bamboos sow the seed for quarrels among neighbours and therefore should not be planted on the land close to neighbours. Bamboo has the potential for transforming once good neighbours into enemies so one should be careful of such aspects before making the decision to plant bamboo.

"Ghosts and spirits lives in the bamboo clumps" and many households were very fearful of bamboo planting very close to the home. This belief is also associated with other tree species such as Pipal (Ficus religiosa) and bar (Ficus benghalensis).

Other commonly held beliefs were (a) Bamboo clumps makes the place dirty with exposed human wastes as many people prefer to use these clumps for toilets; (b) Thieves and robbers hide in dense bamboo clumps; (c) Its shade is bad and inauspicious and brings bad health so should not be planted very close to the house; (d) Those who plant will certainly die early as "bamboos wish to grow very quickly so that it can carry the planter (serve the master) for the final journey to the cremation site"; (e) Women have a menstrual cycle and are impure so bamboo cannot be successfully grown by them; (f) The person who steals bamboo from somebody else's clumps will have no future generation or will fare badly; (g) Men die if bamboo's shadow falls on him during planting; (h) Bamboo dies if planter's shadow falls on bamboos during planting; and (i) Bamboos will not grow if planted by young adults or children (mentioned by $0.50 \%$ or 1 household).

The findings indicate that there are strong superstitions, taboos and beliefs that could have negative impacts on bamboo planting despite the fact that bamboo is an attractive land use option for many households.

\section{The Midhills}

The level of beliefs in superstitions and taboos is significantly lower in the Midhills than in the Terai and is similar to Kerabari. Some $38 \%$ of the households believed in the superstitions and taboos associated with bamboos Like in the Terai, the most commonly held belief in the Midhills against bamboo planting was that it reduces the productivity of land. Bamboos were not planted near the wet khet land and even the rainfed bari land because of the fear that it will reduce the productivity of the land. The fallen, dry leaves of the bamboo on the ground were also mentioned by some as unhelpful in enhancing productivity. As mentioned early, there is some truth in this belief and therefore it was not considered further.

The most commonly heard and believed taboos and superstitions, like in the Terai was that women should not carry out bamboo planting (usually not applied to women whose menstrual cycle has stopped) as it can make them infertile and also because they have menstrual cycle and are too impure to carry out bamboo planting. Many of the households also insisted that women should not carry out bamboo planting because traditionally it is not their job (men's job) and one should not go against tradition. It was also found that the level of belief in such taboo/ superstition was not as strong as in the Terai.

The second most commonly heard and believed superstition was that bamboo planting should not be carried out by young adult male members as it can make them infertile. Bamboo planting was considered inauspicious by some households and should not be carried by young members as it can bring bad health. However, not all of the households who heard such taboo/superstition believed the statement. 
The third most commonly heard and believed taboo or superstition was that only household heads older than 60 years should do bamboo planting. In the absence of old age members in the family it can be carried out by the middle aged household heads or members (40 years or over). Many households said that only the oldest male members should carry out bamboo planting because of the superstition that bamboo planters do not survive long.

The fourth most common superstition in the Midhills was that a person who plants bamboo would die if the bamboo's shadow falls on him at the time of planting. Another superstition was that bamboos would die if the planter's shadow falls on the bamboos at the time of planting. The best time for planting bamboos was at sunset time when planters and bamboos shadows do not fall on each other.

Other beliefs were (a) Bamboo must not be planted at midday or early afternoon; (b) Its shade is inauspicious and brings bad luck and health and therefore should not be planted in front of the home; (c) Bamboos sow the seed of quarrel among neighbours and therefore should not be planted in the land close to neighbours; (d) Bamboo planters will die very early; (e) bamboo does not grow if it is planted by women; (f) Ghosts and spirits live in bamboo clumps and therefore should not be planted very close to the home; ( $\mathrm{g}$ ) If bamboo is planted and does not grow well that is an indication of a bleak future for the family; (h)Thieves hide in clumps if it is very dense; (i) Bamboo plants die after flowering which is inauspicious; and ( $j$ ) Bamboo should only be planted using male labourers and must not be planted by any family members.

Similarly, one household each mentioned beliefs such as new bamboo shoots of Mal bans must not be broken by men or women as it will bring sorrow to the family; only good people are able to propagate bamboo successfully; too much expansion of bamboo will bring a dark future; bamboo propagation is successful only if it done in March or April (it is to be noted that bamboo from traditional method can be successfully propagated even in May, June or July); and ainjeru (massive aerial branching in the upper portion of standing culms) is an indication of future burdening with loans.

\section{Kerabari}

Almost all the households in Kerabari VDC (Morang district) are of hill ethnic origin most of whom had migrated in the last 40 years and the cultural and farming practices are similar to the Midhills. The households also have similar beliefs against bamboo planting as in the Midhills except some beliefs, which were site specific, being surrounded by sal forest. The percentage of the households who believed in superstitions and taboos was significantly lower than in the Terai and just a little higher than in the Midhills.

Like in the Terai and the Midhills, the most commonly held belief against bamboo planting was that it reduces the productivity of the land.

Bamboos sow the seed of quarrel among friendly neighbours and therefore should not be planted on land close to neighbours. As bamboo clump planted near the boundary will expand into neighbours land and the problems start when the planter claims the right of ownership. The other problem is that the commonly held belief like bamboo reduces the productivity of the soil can create suspicion in the mind of neighbours about the motive for bamboo planting.

Bamboo clumps invites wild elephants, poisonous snakes and insects. The households were more fearful of wild elephants than snakes as bamboo is one of the species favoured by wild elephants. Kerabari lies on the migratory route of wild elephants and every 2-3 years wild elephants roam around Kerabari and damage crops of the households and sometimes even attack men. As there is some rationality behind this statement it was not considered further.

Almost all the households that had migrated from the neighbouring Midhills mentioned that women must not plant bamboos as it can make them infertile. The other most commonly heard and held taboos/ superstitions was that young and unmarried males must not plant bamboos as it can make them infertile and they will die unnaturally.

The other most commonly held taboos/ superstitions/beliefs in Kerabari were: (a) Bamboo planters die if its shadow falls on him/her at the time of planting; (b) Bamboo planting should be carried out only by the oldest male household members or the household head; (c) Bamboo dies if the planter's shadow falls on bamboos at the time of planting; (d) Those who plant will die early; (e) Bamboo makes place dirty as people use clumps for toilets; (f) Ghosts and spirits live in bamboo clumps; 
(f) New shoots of Mal bans should not be broken by men or women as it brings sorrow; (g) Women can not propagate bamboo successfully; (h) Its shade is bad and inauspicious so should not be planted in front of the house; and (i) It must not be planted in broad daylight.

\section{Beliefs, superstitions and Taboos associated with other aspects of bamboos}

It was found that there is a general belief among the households that bamboos should not be felled on Tuesday and that the women must not cut bamboo culms. Some households in the Midhills mentioned that only males over 50 years of age should carry out harvesting of new shoots. It was also commonly believed, both in the Terai and the Midhills, that bamboo culms felled in the dark (no moon period) will not be attacked by termites and insect borers.

It was found, however, that beliefs in such superstitions and taboos were not so strong among the younger generation but were still prevalent in the older age groups, both in the Terai and the Midhills.

\section{Level of Belief in Superstitions and Taboos in the Study Area}

The beliefs in statements, which do not have any valid scientific reason, or without any rational explanation were considered superstitions and taboos in the present study. The beliefs in superstitions and taboos, which can prevent households, or affect their decision, to plant or not plant bamboos, were identified. The most common superstitions and taboos which can affect bamboo planting were women must/should not plant bamboo as they will be infertile or because they were impure; young and unmarried male adults must not plant bamboos; planting should be carried out only by the oldest household male members of the household; the bamboos shadow is bad and inauspicious so they should not be planted in front of the home; if bamboo's shadow falls on the planter then he will die.

Based on discussions with households and their responses, the beliefs in superstitions and taboos against bamboo planting were classified into five categories. They were (a) strongly believe, (b) believe, (c) do not know, (d) do not believe, and (e) strongly disbelieve (Table 2).

It can be seen that the percentage of the households who strongly believe in superstitions and taboos against bamboo planting was significantly higher in the Terai than in the Midhills and Kerabari. In Kerabari, there were no households who strongly believed in superstitions and taboos against bamboo planting.

The percentage of the households who believed in the superstitions and taboos against bamboos planting but not very strongly in the Terai, Midhills and Kerabari was significantly higher in the Terai than in the Midhills and Kerabari.

The percentage of the households in "do not know" category was higher in the Midhills and Kerabari than in the Terai.

More households said that they did not believe in the Midhills and Kerabari. There were no households in the Terai who strongly disbelieved in the superstitions and taboos against bamboo planting. It is expected that those households who do not know or who do not believe in superstitions and taboos can be more easily motivated towards bamboo planting than those households who believe/strongly believe in those superstitions and taboos which inhibits bamboo planting.

Table 2 Level of beliefs in superstitions and taboos against bamboo planting in the Terai, the Midhills and Kerabari

\begin{tabular}{|c|c|c|c|c|c|c|}
\hline \multirow{2}{*}{$\begin{array}{l}\text { Level of belief in } \\
\text { Superstitions and Taboos }\end{array}$} & \multicolumn{2}{|c|}{$\begin{array}{c}\text { Terai } \\
(\mathrm{N}=199)\end{array}$} & \multicolumn{2}{|c|}{$\begin{array}{l}\text { Midhills } \\
(\mathrm{N}=208)\end{array}$} & \multicolumn{2}{|c|}{$\begin{array}{c}\text { Kerabari } \\
(\mathrm{N}=41)\end{array}$} \\
\hline & HH No. & $\%$ & HH. No. & $\%$ & HH. No. & $\%$ \\
\hline Strongly believe & 28 & 14.07 & 16 & 7.69 & 0 & 0.00 \\
\hline Believe & 111 & 55.78 & 63 & 30.29 & 16 & 39.02 \\
\hline Do not Know & 6 & 3.02 & 23 & 11.06 & 4 & 9.76 \\
\hline Do not believe & 54 & 27.14 & 102 & 49.04 & 19 & 46.34 \\
\hline Strongly disbelieve & 0 & 0.00 & 4 & 1.92 & 2 & 4.88 \\
\hline All & 199 & 100.00 & 208 & 100.00 & 41 & 100.00 \\
\hline
\end{tabular}




\section{Association between bamboo growing and superstitions and/or taboos against bamboo planting}

The present section will investigate whether there is an association between bamboo growing and superstitions and/or taboos against bamboo growing. Bamboo growers and nongrowers were classified into two categories: (a) those who believed in the superstitions and/or taboos against bamboo planting; and (b) those who did not believe. The statistical significance of any association was examined using the Chi-square test (Appendix 1, 2 and 3).

It was found that there was a statistically significant association between bamboo growing and superstitions and/or taboos against bamboo planting in the Terai. Those who believe in superstitions and/ or taboos are less likely to grow than those who do not believe. There is no strong association between bamboo growing and superstitions and/or taboos against bamboo planting in the Midhills and Kerabari. This means that bamboo growing was carried out even by those households, which believed in these superstitions, and/or taboos, which discourage bamboo planting. Similarly, there were some bamboo nongrowers who did not believe but cannot carry out because of their poor economic situation.

It was also found that in general those households or individuals who were educated (completed high school level study or over) were less superstitious than the non-educated and also have no or less belief in taboos against bamboo planting. The household heads of Brabmin and Chbetri ethnic origin in the Midhills villages who were in general better off and more resourceful than other ethnic groups (except some households of Matawalis ethnic groups whose family members are/were either in the British army or had worked overseas) believed more in superstitions and taboos that discourage bamboo planting. Taboos like women should not plant bamboos were more strongly believed by Brahmins and Chbetri ethnic groups than Matwalis (Middle castes). The study also found that such beliefs were stronger in older age groups than in younger age groups. The findings of focus group studies suggest that beliefs in superstitions and taboos that discourage bamboo planting are stronger in women than men and less among educated than the uneducated.

\section{Conclusion}

The study shows that superstitions and taboos against bamboo planting have some effect on bamboo growing in the Terai but have no significant effect in the Midhills and Kerabari. It seems that households carried out bamboo planting despite having serious reservations along with many superstitions and taboos that discourage bamboo planting because the benefits that accrue from bamboo planting are far higher than so-called risks (superstitions like "will die early", "infertility") and disbenefits ("reduced production").

However, it can be said that had there been no superstitions and/or taboos that discourage bamboo planting, there would have been more bamboo clumps on private land than at present. Any programmes aim at promoting bamboo development in Nepal should take into consideration the effect of such taboos and superstitions on households' decision-making. An increased literacy and education level in future will help people in the study area to overcome these superstitions and taboos. Effective extension work by the development agencies and local non-governmental organisations to remove such superstitions and/or taboos from the minds of the people will be helpful to increase bamboo planting.

\section{References}

Arens, J. and Beurden, J. 1978. Jhagrapur: Poor Peasants and Women in a Village in Bangladesh. Third World Publications, Birmingham, UK. 189 pp.

Blowfield, M. 1995. Bamboo and Poverty. Working Paper 2, Integrated Rural Bamboo Project, Forestry Research Programme, DFID, UK. 4 pp.

Boa, E.R. 1995. Knowing Bamboo, Knowing People. Working Paper 1, Integrated Rural Bamboo Project, Forestry Research Programme, DFID, UK. 4 pp.

Carter, E.J. 1991. Tree Cultivation on Private Land on the Middle Hills of Nepal. A Thesis Presented for the PhD degree at the Oxford University, UK.

Chambers R., Saxena, N.C. and Shah, T. 1989. To the Hands of the Poor: Water and Trees. Intermediate Technology Publications, London, UK. 273 pp.

Das, A.N. 1992. The Potential of Bamboo Growing in Rural Development Forestry in Nepal. M.Sc. (Forest Management) Dissertation, University of Aberdeen. 
Das, A.N. 1999 a. Socioeconomics of Bamboos in Eastern Nepal. PhD Thesis, University of Aberdeen, UK.

Das, A.N. 1999 b. Perception and Attitudes toward Tree Growing in the Terai and Midhills of eastern Nepal. Banko Janakari, 9 (2).

Das, A.N. 2002. Bamboo Growing and its Market Development Potential for Sustaining Rural Livelihoods and Poverty Reduction in Eastern Nepal. Banko Janakari, 12 (2).

Das, A.N. 2004. Manual of Bamboos in Nepal. TISC/NARMSAP, DANIDA, Kathmandu, Nepal.

Foley, G. and Barnard, G. 1984. Farm and Community Forestry. International Institute for Environment and Development (IIED). Earthscan, London. 236 pp.

Gurung, S.M. 1989. Human Perception of Mountain Hazards in the Kakani-Kathmandu area: Experiences from the Middle Mountains of Nepal. Mountain Research and Development, 9 (4): 353-364.

Kwesiga, F. and Chisumpa, S.M. 1990. Ethnobotanical Survey in Eastern Province, Zambia. Draft Report. ICRAF, Nairobi.

Poudyal, S.K. and Das, A.N. 2002. Bamboo Research and Development in Nepal. Journal of Forest and Livelihood, 2 (1): 59-61, Forest Action, Kathmandu, Nepal.
Piper, J.M. 1992. Bamboo and Rattan. Oxford University Press, UK. 120 pp.

Raintree, J.B. 1991. Socioeconomic Attributes of Trees and Tree Planting Practices. Community Forestry Note 9, FAO, Rome. 115 pp.

Ratikette, P, Samsnasang, P., Ratnapanya, S., and Samarang, H. 1992. Taboos and Traditions: their Influence on the Conservation and Exploration of Trees in Social Forestry Projects in Northeastern Thailand. In: Y.S. Rao, N.T. Vergara and G.W. Lovelace (eds.), Community Forestry: Socioeconomic Aspects. FAO, Rome. pp 363-369.

Shepherd, Gill 1992. Forest Management for Forest Production by Indigenous Communities. In: F.R. Miller and K.L. Adam, Wise management of Tropical Forests. Proceedings of Oxford Conference, 29 March-1 April 1992, Oxford. pp 111-124.

Singh, K.A.; Singh, P. and Roy, L.N. 1992. Effect of Bamboo (Bambusa nutans wall. ex Munro) Shade on the Yield of Some Agricultural Crops at Mid Hills of Eastern Himalaya. Indian Journal of Forestry, 15 (4): 339-341.

Wilson, K.B. 1989. Trees in Fields in Southern Zimbabwe. Journal of Southern African Studies, 15: 369-83.

Wood, P.J. 1966. A Guide to Grow Trees in Sukumaland. Technical Note (New Series), Silviculture Section, Lushoto. 
Appendix 1 Association between bamboo growing and superstitions and taboos that discourages bamboo planting in the Terai

\begin{tabular}{|c|c|c|}
\hline \multirow{2}{*}{$\begin{array}{l}\text { Count } \\
\% \text { of Row } \\
\% \text { of Column }\end{array}$} & \multicolumn{2}{|c|}{$\begin{array}{l}\text { Superstitions and taboos that discourages bamboo planting } \\
\text { in the Terai }\end{array}$} \\
\hline & Do not Believe & Believe \\
\hline Nongrowers & $\begin{array}{c}19 \\
21.84 \\
31.67\end{array}$ & $\begin{array}{c}68 \\
78.16 \\
48.92\end{array}$ \\
\hline Grower & $\begin{array}{c}41 \\
36.61 \\
68.33 \\
\end{array}$ & $\begin{array}{c}71 \\
63.39 \\
51.08 \\
\end{array}$ \\
\hline $\begin{array}{l}\text { All } \\
\text { Col umn \% }\end{array}$ & $\begin{array}{c}60 \\
30.15\end{array}$ & $\begin{array}{c}139 \\
69.85\end{array}$ \\
\hline
\end{tabular}

Appendix 2 Association between bamboo growing and superstitions and taboos that discourages bamboo planting in the Midhills

\begin{tabular}{|l|c|c|}
\hline \multirow{2}{*}{$\begin{array}{l}\text { Count } \\
\text { \% of Row } \\
\text { \% of Column }\end{array}$} & \multicolumn{2}{|c|}{$\begin{array}{c}\text { Superstitions and taboos that discourages bamboo planting in } \\
\text { the Midhills }\end{array}$} \\
\cline { 2 - 3 } & Do not believe & Believe \\
\hline Nongrowers & 31 & 12 \\
& 72.09 & 27.91 \\
& 24.03 & 15.19 \\
\hline \multirow{3}{*}{ Grower } & 98 & 67 \\
& 59.39 & 40.61 \\
All & 75.97 & 84.81 \\
Column \% & 129 & 79 \\
\hline
\end{tabular}

Chi-Square $=2.335, \mathrm{DF}=1, \mathrm{P}-$ Value $=0.126$

Appendix 3 Association between bamboo growing and superstitions and taboos that discourages bamboo planting in Kerabari

\begin{tabular}{|l|c|c|}
\hline \multirow{2}{*}{$\begin{array}{l}\text { Count } \\
\% \text { of Row } \\
\text { \% of Column }\end{array}$} & \multicolumn{2}{|c|}{$\begin{array}{c}\text { Superstitions and taboos that discourages bamboo planting in } \\
\text { the Terai }\end{array}$} \\
\cline { 2 - 3 } & Do not Believe & Believe \\
\hline \multirow{3}{*}{ Nongrowers } & 9 & 6 \\
& 60.00 & 40.00 \\
\hline & 36.00 & 37.50 \\
Grower & 16 & 10 \\
& 61.54 & 38.46 \\
\hline All & 64.00 & 62.50 \\
Column \% & 25 & 39.02 \\
\hline
\end{tabular}

Chi-Square $=0.009, \mathrm{DF}=1, \mathrm{P}-$ Value $=0.923$ 